\title{
Peran Mikroba Dekomposer Selulolitik dari Sarang Rayap dalam Menurunkan Kandungan Selulosa Limbah Pertanian Berselulosa Tinggi
}

\author{
Mieke Rochimi Setiawati1), Nizar Ufah ${ }^{2)}$, Reginawanti Hindersah ${ }^{1)}$ dan Pujawati Suryatmana1) \\ 1)Departemen Ilmu Tanah dan Sumberdaya Lahan, Fakultas Pertanian Universitas Padjadjaran \\ 2)Program Studi Magister Ilmu Tanah, Fakultas Pertanian Universitas Padjadjaran \\ Jl. Raya Bandung Sumedang Km 21 Jatinangor \\ Korespondensi: m.setiawati@unpad.ac.id
}

\begin{abstract}
Agricultural waste is rich in cellulosic material that is difficult to degrade but can be decomposed by cellulase enzymes. Cellulosic material is an organic component abundantly in nature in the form of cellulose and hemicellulose polymer. Utilization of microbes in the process of waste bioconversion can be done to get added value from the waste material into other products such as organic fertilizer. Cellulase-producing microbes can be isolated from various sources, one of which is from termite nests. The use of microbes from termite nests as decomposers for composting high-yielding agricultural waste was carried out in this study. Cellulolytic microbial isolates (combination of bacteria and fungi and without decomposers) were applied to agricultural wastes high in cellulose content: rice straw, bagasse, and oil palm empty fruit bunches. Randomized Block Design was applied and each treatment was and repeated 3 times. The composting process was carried out for 1 month indoors. The results showed that cellulolytic microbial consortium obtained from termite nests reduced the compost cellulose content of bagasse agricultural waste in one month. Whereas rice straw and oil palm empty fruit bunches showed a tendency to decrease cellulose content because cellulose degradation by decomposer microbes still continues after one month of incubation.
\end{abstract}

Keywords: agricultural waste, cellulose, decomposers, termite nests

\section{PENDAHULUAN}

Ketergantungan akan pupuk kimia yang terjadi pada petani dapat disebabkan karena upaya petani dalam meningkatkan produksi dan produktivitas komoditas pertanian. Sebagian besar lahan mengalami penurunan bahan organik sampai pada kategori rendah $<<$ $2 \%$ ), sedakan kandungan bahan organik yang optimal $>3 \%$. Hal ini dikarenakan penggunaan lahan secara terus menerus. Penggunaan pupuk buatan dengan dosis tinggi yang tidak proporsional, akan berdampak terhadap ketimpangan status usur hara di dalam tanah, sehingga kekahatan unsur hara lain akan memungkinkan terjadi.

Sebagian petani mulai banyak meninggalkan pemakaian pupuk organik, karena beranggapan pemakaian pupuk organik kurang efisien dan efektif. Hal ini dikarenakan kandungan unsur hara di dalam bahan organik yang relatif rendah dan ketersediannya lambat.
Akibatnya akan berdampak terhadap penurunan kandungan bahan organik tanah. Lahan-lahan di Indonesia sebagian besar kandungan bahan organiknya sudah mencapai pada tingkat yang rawan (Juarsah, 1999).

Menurut Sugito dkk. (1995), kurang lebih 60 persen lahan sawah di pulau Jawa mengandung bahan organik kurang dari 1 persen. Sedangkan sistim pertanian dapat disebut berkelanjutan bila kandungan bahan organik tanah lebih dari $2 \%$. Walaupun kuantitas nutrisi bahan organik rendah terhadap suplai hara bagi tanaman, namun peran bahan organik yang paling terpenting adalah berkaitan dengan penyangga hara di dalam tanah sehingga nutrisi dalam keadaan tersedia dan juga berperan terhadap sifat fisik tanah. Menurut Stevenson (1994), apabila di dalam tanah kandungan humus semakin berkurang, akibatnya lambat laun tanah akan 
menjadi kompak, keras, dan bergumpal, sehingga menjadi kurang produktif.

Apabila C organik tanah kurang dari $2 \%$ pada tanah sawah sering disebut sebagai tanah sakit (Setyorini et al., 2006). Kondisi ini disebabkan oleh penanaman intensif dan semua sisa-sisa tanaman diangkut keluar, sedangkan untuk mendapatkan produktivitas lahan yang optimal, kandungan organik $\mathrm{C}$ harus lebih dari 2,5\%. Semakin rendah bahan organik dapat membuat semakin rendah produktivitas tanah. Aplikasi bahan organik ke dalam tanah menyebabkan peningkatan kandungan karbon yang mempengaruhi peningkatan produktivitas tanah, peningkatan pasokan nutrisi untuk tanaman, dan percepatan siklus nutrisi di dalam tanah. Upaya mengembalikan kesehatan dan kesuburan tanah dapat ditempuh dengan meningkatkan kandungan bahan organik tanah hingga $>2 \%$. Menurut Mulyani et al. (2012) sekitar 73\% lahan sawah (sekitar 5 juta ha) memiliki Corganik yang sangat rendah (C -organik $<2 \%$ ), 22\% memiliki konten C-organik sedang (2 - 3\% C-org) dan 4\% memiliki konten C-organik yang tinggi (> 3\% C-org). Upaya memulihkan kesehatan dan kesuburan tanah dapat dilakukan dengan memanfaatkan sumber $\mathrm{C}$ organik potensi lokal seperti jerami padi, brangkasan jagung, serasah tanaman dll.

Limbah pertanian yang berlimpah akan mempunyai nilai lebih apabila diolah lebih lanjut, sebagai contoh limbah pertanian dibuat pupuk organik. Limbah pertanian banyak mengandung bahan lignoselulosa yang dapat diuraikan oleh selulase. Bahan lignoselulosa merupakan komponen organik berlimpah di alam. Lignoselulosa terdiri dari tiga polimer yaitu selulosa, hemiselulosa, dan lignin. Bahan lignoselulosa banyak terdapat pada limbah pertanian seperti jerami padi, brangkasan jagung, dan tandan kosong kelapa sawit. Jaringan tanaman tersusun dari komponen terbesar yaitu selulosa (35-50\%), hemiselulosa
(20-35\%) dan lignin (10-25\%). Selulosa merupakan polimer linier dari D-glukosa yang terikat pada ikatan 1,4 glikosidik dan sangat kuat berasosiasi dengan hemiselulosa dan lignin (Saha, 2004). Di dalam perkembangan bioteknologi pemanfaatan mikroba di dalam proses biokonversi limbah dilakukan untuk diperoleh nilai tambah dari bahan limbah tersebut menjadi produk lain seperti pupuk organik. Berbagai jenis mikroorganisma seperti bakteri, jamur, dan aktinomiset dikenal dapat menghasilkan enzim selulase. Selulase adalah enzim kompleks yang memutuskan secara bertahap rantai selulosa menjadi glukosa. Enzim ini terdiri dari eksobiohidrolase atau eksoselulase, endo $\beta$ 1,4-glukanase atau endoselulase dan selobiase atau $\beta$-1,4-glukosidase (Gerhartz, 1990).

Mikroba penghasil enzim selulosa dapat diisolasi dari berbagai sumber, salah satunya dari aktivitas rayap yang berupa gundukan tanah rayap. Pada koloni rayap, rayap pekerja memakan serat kayu yang kaya akan selulosa. Sistem pencernaan rayap mempunyai enzim selulose dan bakteri yang dapat membantu untuk mencerna serat kayu. Dengan demikian, rayap dan mikroba penghasil enzim selulase yang berada pada pencernaan rayap bersimbiosis mutualisme atau saling mengguntungkan. Penggunaan mikrobia asal tanah rayap sebagai bioaktivator pengkomposan limbah pertanian yang berselulosa tinggi akan dilakukan pada penelitian ini. Selain itu pada gundukan tanah rayap terdapat berbagai bakteri yang menguntungkan rayap termasuk bakteri dekomposer yang dapat mengancurkan bahan organik berselulosa tinggi. Gundukan tanah dibangun oleh rayap dari kotoran rayap direkatkan satu partikel dengan partikel lain, dengan bahan perekat berupa air liur dan atau senyawa ekskresi lainnya (Yanagawa et al., 2012). 
Dampak negatif dapat terjadi terhadap ketersediaan hara tanah bila bahan organik yang masih mentah dengan rasio $\mathrm{C} / \mathrm{N}$ tinggi diberikan secara langsung ke dalam tanah. Mikrobia akan menggunakan bahan organik secara langsung untuk mendapatkan energi. Untuk tumbuh dan berkembang populasi suatu mikrobia yang tinggi di dalam tanah membutuhkan hara yang diambil dari tanah yang seharusnya digunakan oleh tanaman, akibatnya hara yang ada diperebutkan oleh tanaman dan mikroba. Unsur hara yang ada di dalam tanah berubah menjadi tidak tersedia karena berubah menjadi senyawa organik mikrobia atau immobilisasi hara. Imobilisasi hara dapat dihindari bila bahan yang mentah dilakukan proses pengomposan terlebih dahulu. Proses pengomposan merupakan suatu proses penguraian bahan organik dari bahan dengan nisbah $\mathrm{C} / \mathrm{N}$ tinggi (mentah) menjadi bahan yang mempunyai nisbah $\mathrm{C} / \mathrm{N}$ rendah kurang dari 15 (matang) dengan cara mengaktifkan aktivitas mikroba dekompuser (bakteri, jamur, dan aktinomiset).

Menurut Setiawati dkk, (2018) peningkatan biomassa-C mikroba tanah dan aktivitas enzimatik tanah sangat tergantung pada jenis pupuk hijau yang diaplikasikan pada tanah. Perbedaan dari rasio $\mathrm{C} / \mathrm{N}$ dari pupuk hijau dalam bentuk yang berbeda diperlihatkan oleh perubahan yang berbeda pada rasio $\mathrm{C} / \mathrm{N}$ tanah. Akibatnya, mineralisasi bahan organik yang diaplikasikan kedalam tanah dilakukan dalam kondisi yang baik dibandingkan proses imobilisasi; hal tersebut ditunjukkan pada nilai tertinggi dari biomassa mikroba tanah dan aktivitas enzimatik tanah.

Tujuan penelitian ini adalah untuk mengkaji dekomposer yang mengandung konsorsium mikroba selulolitik dari sarang rayap yang diaplikasikan pada limbah pertanian yang berselulosa tinggi sehingga dapat menurunkan kandungan selulosa bahan kompos dan mempercepat proses degradasi bahan organik.

\section{METODOLOGI}

Mikroba selulolitik diisolasi dari sarang rayap menggunakan media selektif yang mengandung CMC (selulosa). Seleksi jamur dan bakteri selulosa dilakukan dengan menguji kemampuannya dalam menghasilkan indeks zona bening selulosa yang tertinggi. Dua jenis isolat bakteri dan jamur yang terpilih dibuat biakan murninya pada agar miring nutien agar dan potato dextrose agar. Starter mikroba dekomposer dibuat dari biakan murni mikroba selulolitik pada media cair PDB, selanjutnya diperbanyak pada media cair molase $3 \%$ yang ditambah 0,2\% yeast ekstrak di dalam Erlenmeyer dengan pengocokan $120 \mathrm{rpm}$ selama 72 jam.

Inokulan isolat mikroba selulolitik (kombinasi bakteri dan jamur serta tanpa dekomposer) diaplikasikan pada cacahan limbah pertanian yang tinggi kandungan selulosa yaitu: jerami padi (berasal dari sawah petani di desa Celes, Jatinangor), ampas tebu (dari Perkebunan Tebu Pabrik Gula Jati tujuh), dan tandan kosong kelapa sawit (dari Perkebunan sawit PTPN Cigudeg Bogor). Kuantitas bahan kompos yang dibuat masingmasing perlakuan mempunyai volume $1 \mathrm{~m}^{3}$ dicetak menggunakan kotak kompos terbuat dari bambu.

Total perlakuan yang dikombinasikan adalah 2 jenis dekomposer (tanpa dan memakai biodekomposer) dengan 3 jenis limbah pertanian, diulang 3 kali (pengambilan sampel). Kompos diformulasikan dengan cara mencampur bahan dasar campuran kompos yaitu dedak $10 \mathrm{~kg}$, kotoran sapi $100 \mathrm{~kg}$ (4 karung) dicampur limbah pertanian (cacahan jerami atau ampas tebu atau tandan kosong kelapa sawit) sesuai perlakuan sampai mencapai volume cetakan kompos $1 \mathrm{~m}^{3}$. Rancangan penelitian Rancangan Acak Kelompok. Proses pengomposan dilakukan selama 1 bulan dengan metode indore. Parameter yang diuji adalah kandungan kadar 
air, C. dan $\mathrm{N}$ serta $\mathrm{C} / \mathrm{N}$, selulosa setelah inkubasi pengomposan (satu bulan).

\section{HASIL DAN PEMBAHASAN}

\subsection{Kadar Air, C, N, dan C/N awal bahan kompos}

Kadar Air, C, N, dan C/N awal bahan kompos merupakan parameter yang penting untuk melihat kandungan kimia awal bahan terutama kandungan karbon organik yang terkandung di dalam bahan dasar penyusun kompos. Karbon organik merupakan bahan penyusun selulosa yang merupakan kandungan terbesar dari sisa-sisa tanaman. Bahan utama kompos berupa jerami padi, ampas tebu, dan TKKS mengandung C (karbon) organik yang tinggi. Ampas tebu dan TKKS mengandung karbon organik yang tinggi dibandingkan dengan jerami (Tabel 1). Formulasi kompos dengan tambahan dedak, dan kotoran sapi menurunkan kandungan $\mathrm{C} / \mathrm{N}$ bahan kompos. Akan tetapi ampas tebu dan TKKS mengadung $\mathrm{C}$ organik yang lebih tinggi (>39\%) dibandingkan formula kompos jerami. $(15,25 \%)$. Syarat bahan kompos yang baik untuk dikomposkan adalah $\mathrm{C}$ organik bahan kompos sekitar 30\%. Disamping itu tambahan dedak dan kotoran sapi meningkatkan $\mathrm{N}$ organik bahan kompos sehingga kandungan $\mathrm{N}$ yang dibutuhkan untuk membentuk biomassa dan pertumbuhan mikroba dekomposer dapat tercukupi. Sumber C diperlukan mikroba untuk sumber energi aktivitasnya (Eiler, et al. 2003) dalam hal ini untuk mendegradasi selulsa (C organik) di dalam kompos.

Tabel 1 Kandungan Kadar Air, C, N, dan C/N awal bahan kompos

\begin{tabular}{lcccc}
\hline \multicolumn{1}{c}{ Jenis bahan kompos } & $\begin{array}{c}\text { Kadar Air } \\
(\%)\end{array}$ & $\begin{array}{c}\text { C organik } \\
(\%)\end{array}$ & $\begin{array}{c}\text { N Total } \\
(\%)\end{array}$ & C/N \\
\hline Jerami & 10,36 & 39,54 & 1,74 & 22,72 \\
Ampas Tebu & 7,92 & 55,24 & 0,74 & 74,65 \\
Tandan Kosong Kelapa Sawit (TKKS) & 10,00 & 52,54 & 1,38 & 38,07 \\
Dedak & 9,92 & 46,24 & 1,72 & 26,88 \\
Kotoran sapi & 34,86 & 19,86 & 1,71 & 11,61 \\
Jerami + Dedak + Kotoran sapi & 28,26 & 15,25 & 1,66 & 9,19 \\
Ampas Tebu + Dedak + Kotoran sapi & 25,16 & 39,94 & 1,14 & 35,04 \\
TKKS + Dedak + Kotoran sapi & 8,66 & 39,28 & 1,63 & 24,10 \\
\hline
\end{tabular}

Proses pembuatan kompos meliputi: pencampuran bahan, inkubasi, pembongkaran kompos, dan pengadukan (Gambar 1). Pengadukan bahan kompos yang dibuat dilakukan untuk menghomogenkan bahan kompos dengan dekomposer $(10 \%$ dari volume kompos) yang diberikan sesuai dengan perlakuan. Perlakuan yang tidak diberi dekomposer ditambahkan air sesuai dengan banyaknya dekomposer yang diberikan.

Bahan TKKS masih mengandung minyak sawit yang masih terdapat pada serat TKKS yang dapat menghalangi aktivitas degradasi mikroba selulolitik. Oleh karena itu cacahan TKKS dilakukan pencucian dahulu dan dijemur selama 3 hari sampai cacahan TKKS tidak terlalu basah/lembab kemudian dilakukan pencampuran dengan bahan-bahan yang akan dikomposkan.

\subsection{Suhu Kompos}

Suhu rata-rata mingguan kompos yang diukur selama satu bulan menunjukkan flktuasi (Tabel 2). Suhu bahan kompos sebelum dicampur/diformulasikan berkisar antara 29० C sampai $30^{\circ}$ C. Setelah satu minggu inkubasi pengomposan, suhu kompos meningkat dibandingkan suhu awalnya. Rata-rata suhu kompos yang diberi dekomposer meningkat lebih tinggi dibandingkan tanpa penambahan 
dekomposer. Demikian pula sama halnya pada masa inkubasi 2 minggu setelah pengomposan (MSP), suhu kompos dari ampas tebu bahkan mencapai $52,3^{\circ} \mathrm{C}$. Hal tersebut menandakan aktivitas mikroba selulolitik menyebabkan peningkatan suhu akibat aktivitasnya dalam merombak bahan lignoselulosa yang beasal dari limbah pertanian.

Tabel 2 Rata-rata suhu kompos selama 4 Minggu Setelah Pengomposan (MSP)

\begin{tabular}{lccccc}
\hline \multirow{2}{*}{ Jenis kompos } & \multicolumn{4}{c}{ Suhu Pengomposan $\left({ }^{\circ} \mathrm{C}\right)$} & \multirow{2}{*}{$\begin{array}{c}\text { Suhu tertinggi } \\
\left({ }^{\circ} \mathrm{C}\right)\end{array}$} \\
\cline { 2 - 5 } & 1 MSP & 2 MSP & 3 MSP & 4 MSP & 54,8 \\
\hline Jerami & 45,2 & 48,2 & 42,1 & 47,3 & 59,9 \\
Jerami + Dekomposer & 47,2 & 52,3 & 39,7 & 44,8 & 52,1 \\
Ampas Tebu & 44,3 & 45,3 & 48,2 & 42,2 & 53,8 \\
Ampas Tebu + Dekomposer & 44,4 & 45,4 & 52,3 & 38,4 & 53,8 \\
TKKS & 39,5 & 41,4 & 42,0 & 44,9 & 53,8 \\
TKKS + Dekomposer & 42,4 & 43,1 & 42,9 & 44,2 & \\
\hline
\end{tabular}

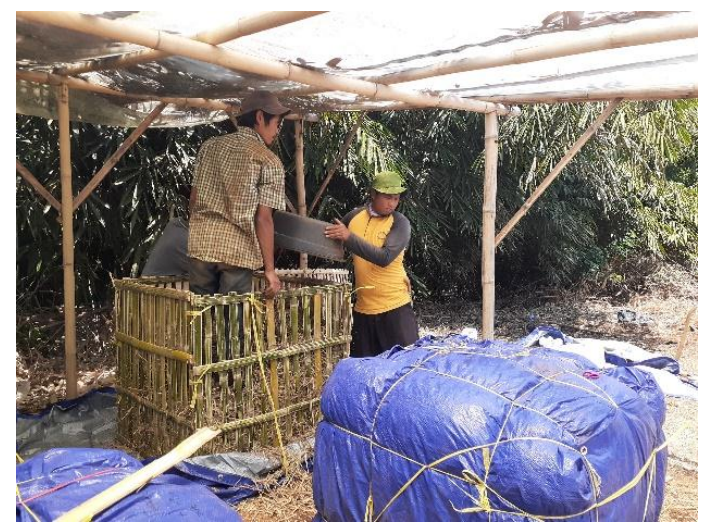

a

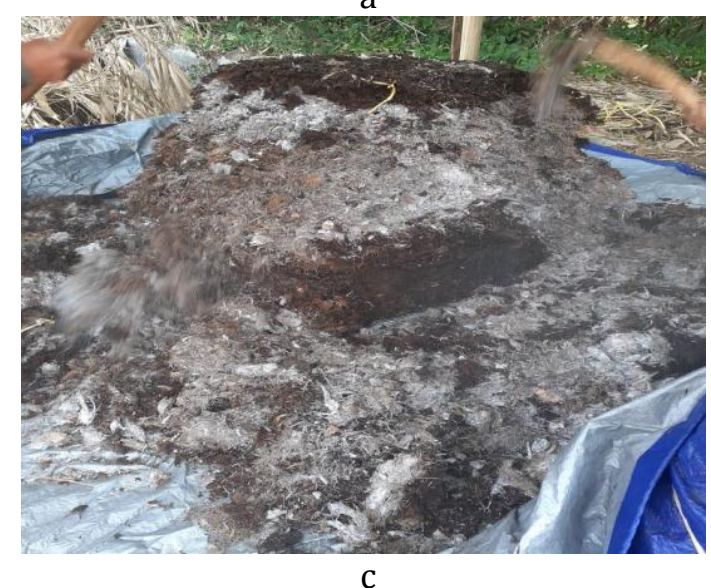

C

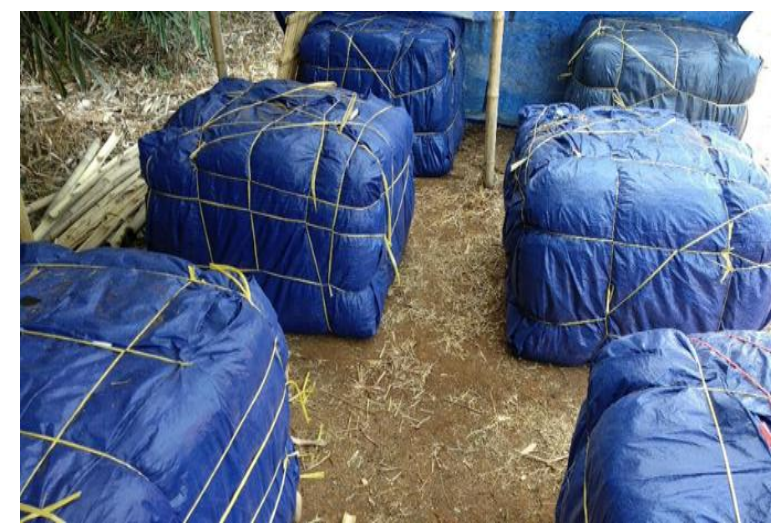

$\mathrm{b}$

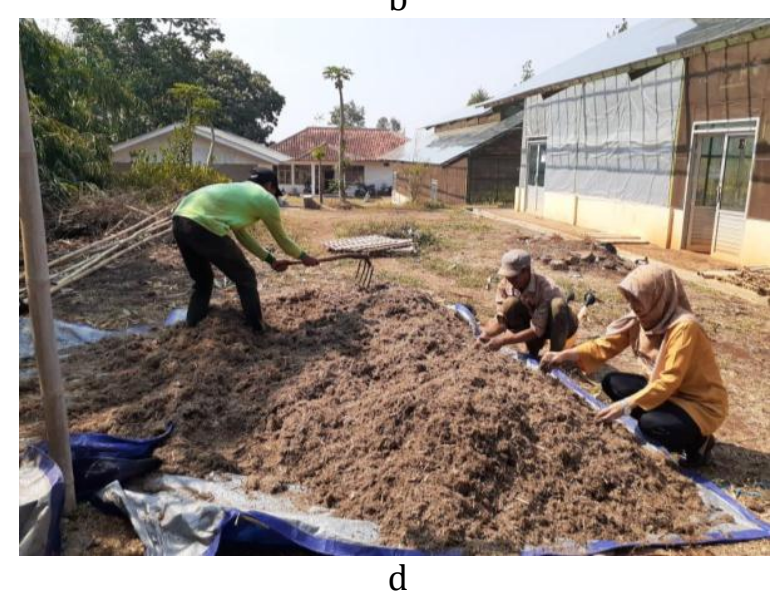

Gambar 1 Proses pembuatan, pembongkaran, dan pengadukan kompos, Pencetakan kompos menggunakan kotak bambu volume $1 \mathrm{~m}^{3}(\mathrm{a})$; Bahan kompos yang telah dibungkus terpal plastik (b); Pembongkaran kompos yang telah ditumbuhi bakteri dan jamur selulolitik (c); dan Pembalikan/pengadukan kompos setelah 2 minggu inkubasi (d). 
Suhu di atas $40^{\circ} \mathrm{C}$ merupakan suhu optimum untuk mikroba termofil. Sedangkan mikroba termofil dikenal banyak dari golongan pendegradasi bahan organik. Suhu tertinggi yang dicapai kompos dari jerami adalah $59,9^{\circ} \mathrm{C}$ suhu yang mendekati temperatur pasteurisasi $\left(>60^{\circ}\right.$ C). Pada suhu pasteurisasi semua mikroba penyebab penyakit dan benih gulma yang terbawa dari bahan kompos akan mati karena suhu pasteurisasi pada proses pengomposan.

Jerami mengandung senyawa karbon yang terkecil dibandingkan dengan bahan utama kompos lainnya (ampas tebu dan tandan kosong kelapa sawit). Pada 3 minggu setelah pengomposan, suhu kompos jerami mengalami penurunan sedangkan suhu kompos lainnya masih mengalami peningkatan. Diduga pada saat itu aktivitas mikroba termofilik mulai digantikan oleh mikroba mesofilik (Chandna et al, 2013). Pada 4 minggu setelah pengomposan suhu kompos ampas tebu mulai menurun sedangkan kompos jerami meningkat kembali sementara kompos dan tandan kosong kelapa sawit (TKKS) konstan terus meningkat.
Pada akhir pengomposan TKKS mulai meningkat suhunya akibat sebagian besar bahan kompos TKKS sudah mulai terdegradasi.

\subsection{Kandungan C, N, C/N, dan selulosa Kompos}

Setelah masa pengomposan 30 hari, terjadi penurunan $\mathrm{C}$ organik dan $\mathrm{C} / \mathrm{N}$ kompos yang menandakan bahwa proses pengomposan berlangsung dengan baik (Tabel 3). Syarat mutu kompos (pupuk organik) yang baik menurut Permentan nomor 70 tahun 2011 yaitu kandungan $\mathrm{C}$ organik minimal $15 \%$ dan $\mathrm{C} / \mathrm{N}$ sebesar $15-25 \%$. Setelah satu bulan proses pengomposan, kompos dengan bahan utama jerami mengandung $\mathrm{C}$ organik dibawah standar permentan sedangkan kompos ampas tebu dan TKKS memenuhi standar mutu pupuk organik Permentan. Kandungan C organik jerami padi yang lebih rendah dari pada kedua bahan organik lainnya yang menyebabkan proses degradasi $\mathrm{C}$ organik oleh mikroba dekomposer maupun mikroba alami (tanpa penambahan dekomposer) berlangsung cepat sehingga kandungan $\mathrm{C}$ organik dibawah $15 \%$.

Tabel 3 Kandungan C, N, C/N, dan selulosa berbagai kombinasi kompos setelah 30 hari inkubasi

\begin{tabular}{|c|c|c|c|c|}
\hline Jenis kompos & $\begin{array}{c}\text { C organik } \\
(\%)\end{array}$ & $\begin{array}{c}\text { N Total } \\
(\%)\end{array}$ & $\mathrm{C} / \mathrm{N}$ & $\begin{array}{c}\text { Selulosa } \\
(\%)\end{array}$ \\
\hline Kompos Jerami + Dedak + Kotoran sapi & $13,22 \mathrm{a}$ & 1,62 & $8,16 \mathrm{a}$ & $24,75 \mathrm{a}$ \\
\hline $\begin{array}{l}\text { Kompos Jerami + Dedak + Kotoran sapi + } \\
\text { Dekomposer }\end{array}$ & $11,43 \mathrm{a}$ & 1.92 & $5,95 \mathrm{a}$ & $22,53 \mathrm{a}$ \\
\hline Kompos Ampas Tebu + Dedak + Kotoran sapi & $30,11 \mathrm{~b}$ & 1,18 & $25,52 \mathrm{~b}$ & $42,34 \mathrm{~b}$ \\
\hline $\begin{array}{l}\text { Kompos Ampas Tebu + Dedak + Kotoran sapi }+ \\
\text { Dekomposer }\end{array}$ & $28,64 \mathrm{~b}$ & 1,83 & $15,65 \mathrm{ab}$ & $34,27 \mathrm{a}$ \\
\hline Kompos TKKS + Dedak + Kotoran sapi & $31,25 \mathrm{~b}$ & 1,69 & $18,49 \mathrm{~b}$ & $49,42 \mathrm{~b}$ \\
\hline $\begin{array}{l}\text { Kompos TKKS + Dedak + Kotoran sapi + } \\
\text { Dekomposer }\end{array}$ & $29,53 \mathrm{~b}$ & 1,73 & $17,06 \mathrm{~b}$ & $40,30 \mathrm{~b}$ \\
\hline
\end{tabular}

Kompos yang diberi dekomposer memperlihatkan tendensi total $\mathrm{N}$ yang lebih tinggi dari pada tanpa pemberian dekomposer walaupun secara statistik tidak nyata. Mikroba selulolitik yang aktivitasnya mendegradasi bahan lignoselulosa ada pula yang berfungsi ganda sebagai penambat $\mathrm{N}_{2}$ dari udara yaitu bakteri selulolitik penambat nitrogen yang mampu mengkonversi nitrogen udara menjadi amonium (Hidayah, 2007), seperti halnya dengan bakteri penambat $\mathrm{N}$ bakteri Azotobacter dan Azospirillum dapat mensuplai $\mathrm{N}$ dari hasil penambatannya dari $\mathrm{N}_{2}$ di udara ke dalam media tumbuhnya. Besarnya 
sumbangan $\mathrm{N}$ yang diberikan oleh bakteri penambat $\mathrm{N}$ di dalam kompos tergantung dari kemampuan bakteri tersebut dalam memfiksasi $\mathrm{N}$ dari udara. Besarnya aktivitas penambatan $\mathrm{N}$ dari udara dapat dianalisis melalui uji Acetylene Reduction Assay (ARA). Beberapa bakteri penambat $\mathrm{N}$ juga menghasilkan hormon tumbuh yang dapat memberi nilai tambah dari produk kompos yang dihasilkan.

Nilai C/N sebesar 15-25\% yang memenuhi standar mutu pupuk organik Permentan, berasal dari kompos TKKS yang mempunyai $\mathrm{C} / \mathrm{N}$ sebesar 18,49 dan 17,06 berturut-turut untuk kompos TKKS tanpa dekomposer dan yang ditambah dekomposer. Nilai C/N kompos yang dihasilkan baik dari bahan utama jerami padi, ampas tebu, dan TKKS tidak berbeda antara yang diberi dekomposer dibandingkan tanpa dekomposer. Kandungan $\mathrm{C} / \mathrm{N}$ dipengaruhi oleh kadar $\mathrm{C}$ organik dan $\mathrm{N}$ total bahan kompos, sehingga rasio awal bahan yang akan dikomposkan menentukan hasil akhir $\mathrm{C} / \mathrm{N}$ kompos. Penambahan pupuk kandang dan dedak selain menambah $\mathrm{N}$ kompos juga dapat menurunkan C/N kompos. Menurut Setyorini dkk (2017) prinsip pengomposan adalah menurunkan rasio $\mathrm{C} / \mathrm{N}$ bahan organik hingga sama dengan $\mathrm{C} / \mathrm{N}$ tanah $(<20)$. Semakin tinggi rasio $\mathrm{C} / \mathrm{N}$ bahan organik maka proses pengomposan atau perombakan bahan organik semakin lama. Waktu yang dibutuhkan bervariasi dari satu bulan hingga beberapa tahun tergantung bahan dasar.

Selulosa dalam bentuk lignoselulosa merupakan komponen organik berlimpah di alam, yang terdiri dari tiga polimer yaitu selulosa, hemiselulosa dan lignin. Komponen terbesar adalah selulosa (35-50\%), hemiselulosa (20-35\%) dan lignin (10-25\%) (Saha, 2004). Senyawa selulosa, hemiselulosa, dan lignin merupakan sumber utama untuk menghasilkan produk menguntungkan seperti gula dari hasil fermentasi, bahan bakar cair, bahan kimia, sumber energi dan karbon.
Perubahan bahan lignoselulosa akibat aktivitas mikroba selulolitik ataupun xilanolitik telah banyak diteliti (Pason dkk, 2003). Selulosa jerami dalam kompos yang dihasilkan mempunyai kandungan yang lebih rendah dibandingkan kandungan selulosa pada kompos ampas tebu dan TKKS.

Pada waktu inkubasi satu bulan, mikroba dekomposer pada kompos jerami, ampas tebu, maupun TKKS dapat menurunkan kandungan selulosa bahan tersebut berturut-turut sebesar 9,85 \%; 23,55 \%; 22,63 \%. Walaupun penurunan selulosa pada kompos jerami dan TKKS tidak berbeda nyata secara statistik, akan tetapi apabila proses dekomposisi dilanjutkan lebih dari satu bulan penurunan/ degradasi selulosa masih berlanjut. Penurunan selulosa pada kompos ampas tebu yang diberi dekomposer berbeda nyata dibandingkan kompos ampas tebu tanpa dekomposer, ini menunjukkan formulasi bahan kompos yang dibuat sesuai sebagai media pertumbuhan yang optimal bagi mikroba pendegradasi selulosa yang ditunjang juga dengan faktor lingkungan seperti suhu, kelembaban, dll.

\section{KESIMPULAN}

Dekomposer konsorsium mikroba selulolitik terdiri dari isolat bakteri dan jamur selulolitik dari sarang rayap dapat menurunkan kandungan selulosa kompos dari limbah pertanian khususnya limbah ampas tebu dalam waktu satu bulan. Sedangkan pada kompos limbah jerami padi dan tandan kosong kelapa sawit (TKKS) dalam masa inkubasi satu bulan memperlihatkan kecenderungan penurunan selulosa karena degradasi selulosa oleh mikroba dekomposer masih berlanjut.

\section{Ucapan Terimaksih}

Ucapkan terima kasih kami sampaikan kepada Universitas Padjadjaran yang telah memberi bantuan dana penelitian melalui skema penelitian Riset Kompetensi Dosen Unpad (RKDU) TA 2019. 


\section{DAFTAR PUSTAKA}

Chandna P., Nain L., Singh S., and Kuhad R.C. 2013. Assessment of bacterial diversity during composting of agricultural byproducts. BMC Microbiol, 13 (99): 114.

Eiler A, Langenheder S, Bertilsson S, and Tranvik L.J. 2003. Heterotrophic bacterial growth efficiency and community structure at different natural organic carbon concentrations. Appl Environ Microbiol, 69(7): 37013709.

Gerhartz, W. 1990. Enzymes in Industry: Production and Applications. VCH Verlagsgesellschaft mbH, WeinheimGerman.

Hidayah L. 2007. Isolasi dan Uji Potensi Bakteri Selulolitik Penambat Nitrogen dari Persawahan Kelurahan Mertojoyo Malang dalam Menghasilkan Amonium $\left(\mathrm{NH}_{4}+\right)$. Skripsi. Universitas Brawijaya.

Juarsah, I. 2000. Manfaat dan alternatif penggunaan pupuk organik pada lahan kering melalui pertanaman leguminosa. Dalam Suyono, A. D., dkk (Eds). Prosiding Konggres Nasional VII HITI. Himpunan Ilmu Tanah Indonesia. Bandung, 2 - 4 November 1999. Hal: $891-900$.

Mulyani A., D. Setyorini, S. Rochyati dan I. Las. 2012. Karakteristik dan sebaran lahan sawah terdegradasi di 8 provinsi sentra produksi padi. Dalam Prosiding Seminar Nasional Teknologi Pemupukan dan Pengelolaan Lahan Terdegradasi. Balai Besar Penelitian dan Pengembangan Sumberdaya Lahan Pertanian. Bogor, 29 - 30 Juni 2012. Hal: $99-110$.

Pason, P., K. Ratanakhanokchai and K.L. Kyu. 2003. Multiple cellulases and xylanases of Bacillus circulans B-6. Biotechnology for Sustainable Utilization of Biological Resources in the Tropics Vol. 16. IC Biotech, Japan. p 305-310.

Saha, B.C. 2003. Hemicellulose Bioconversion. J. Ind. Microbiol. Biotechnol. 30(5): 279-291.

Setiawati, M.R. P. Suryatmana, Budiasih, N. Sondari, L. Nurlina, B.A. Kurnani and E. Harlia. 2018. Utilization Azolla pinnata as substitution of manure to improve organic rice yield and paddy soil health. IOP Conference Series: Earth and Environmental Science 215(2018): 0123006

Setyorini, D., Saraswati R., dan Anwar E.K. 2006. Kompos. Dalam Simanungkalit et. al (Eds). Pupuk Organik dan Pupuk Hayati. Balai Besar Litbang Sumberdaya Lahan Pertanian. Bogor.

Stevenson F. J. 1994. Humus Chemistry: Genesis, Composition, Reactions, 2nd Edition, published by Wiley.

Sugito, Y., Y. Nuraini dan E. Nihayati. 1995. Sistem Pertanian Organik. Fakultas Pertanian Universitas brawijaya. Malang.

Yanagawa A, N. Fujiwara-Tsujii, T. Akino, T. Yoshimura, T. Yanagawa, S. Shimizu. 2011. Behavioral changes in the termite, Coptotermes formosanus (Isoptera), inoculated with six fungal isolates. Journal of Invertebrata Pathology, 107(2): 100-106 